\title{
Application of veno-venous extracorporeal membrane oxygenation in lymphoma patients with severe acute respiratory distress syndrome: a case series
}

\section{Primjena veno-venske izvantjelesne membranske oksigenacije kod pacijenata s limfomom i teškim akutnim respiratornim distresnim sindromom: serija slučajeva}

\author{
Dorian Tokmadžić ${ }^{1 *}$, Kazimir Juričić ${ }^{2}$, Matilda Novosel ${ }^{1}$, Alen Protić ${ }^{2}$
}

\begin{abstract}
Aim: To report the clinical courses of two patients, one with Hodgkin's lymphoma $(\mathrm{HL})$ and one with Non-Hodgkin's lymphoma (NHL), who developed severe refractory acute respiratory distress syndrome (ARDS) and were treated with veno-venous extracorporeal membrane oxygenation (VV ECMO). Case report: Both patients developed chemotherapyassociated febrile neutropenia followed by pneumonia and ARDS, after which they were transferred to the intensive care unit. Their respiratory failure deteriorated despite endotracheal intubation with protective mechanical ventilation, at which point a decision for VV ECMO initiation was made. Both patients had complicated treatment courses and developed severe ECMO-associated complications. The most important complications of ECMO support in our HL patient were cardiac arrest; right atrial laceration with pericardial tamponade which needed surgical treatment; right leg ischemia which required transfemoral amputation; thrombosis within the membrane oxygenator; several septic episodes with severe hemodynamic instability; and right sided tension pneumothorax. Despite all difficulties, the patient was successfully weaned from ECMO. Unfortunately, he died prior to hospital discharge as a result of sepsis with multiple organ failure. The most significant ECMO-induced complications in our NHL patient were severe bleeding incidents, most notably diffuse oropharyngeal and continuous bilateral pulmonary hemorrhage; superimposed bacterial pneumonia; extensive pneumomediastinum and subcutaneous emphysema. Despite all therapeutic efforts, the patient died during ECMO treatment because of respiratory decompensation. Conclusions: The patients with hematologic malignancies (HMs) undergoing ECMO support have poor outcomes, with high rates of severe ECMO-induced complications. Further studies focusing on patient selection and issues concerning prevention, diagnosis and treatment of ECMO-associated complications are needed.
\end{abstract}

Key words: adult respiratory distress syndrome; extracorporeal membrane oxygenation; hematologic neoplasms; Hodgkin disease; Non-Hodgkin lymphoma

Sažetak. Cilj: Prikazati klinički tijek dvoje pacijenata, pacijenta s Hodgkinovim limfomom i pacijentice s ne-Hodgkinovim limfomom, koji su razvili teški refraktorni akutni respiratoracijski distresni sindrom (engl. acute respiratory distress syndrome; ARDS) te su liječeni veno-venskom izvantjelesnom membranskom oksigenacijom (engl. veno-venous extracorporeal membrane

Napomena: Prikaz slučaja izrađen je u sklopu radionice „Kako napisati dobar prikaz slučaja?“ u organizaciji časopisa Medicina Fluminensis (autorica i voditeljica radionice: doc. dr. sc. Nina Pereza, dr. med.).
${ }^{1}$ Medicinski fakultet, Sveučilište u Rijeci, Rijeka, Hrvatska

${ }^{2}$ Klinika za anesteziologiju i intenzivno liječenje, KBC Rijeka, Rijeka, Hrvatska

${ }^{*}$ Corresponding author:

Dorian Tokmadžić

Medicinski fakultet, Sveučilište u Rijeci Braće Branchetta 20, 51000 Rijeka

E-mail: dorian.tokmadzic@gmail.com

http://hrcak.srce.hr/medicina 
oxygenation; VV ECMO). Prikaz slučaja: Nakon kemoterapije pacijenti su razvili febrilnu neutropeniju, pneumoniju i ARDS, nakon čega su premješteni u jedinicu intenzivnog liječenja. Unatoč orotrahealnoj intubaciji i protektivnoj mehaničkoj ventilacijskoj potpori, došlo je do pogoršanja njihova respiracijskog statusa te se odlučilo uvesti VV ECMO potporu. Imali su kompliciran klinički tijek praćen teškim komplikacijama povezanim s korištenjem ECMO-a. Kod pacijenta s Hodgkinovim limfomom razvile su se sljedeće komplikacije: kardijalni arest; laceracija aurikule desnog atrija s tamponadom perikarda, što je zahtijevalo kirurško liječenje; ishemija desne noge koja je zahtijevala transfemoralnu amputaciju; tromboza membranskog oksigenatora; nekoliko septičkih epizoda praćenih teškom hemodinamskom nestabilnošću te desnostrani tenzijski pneumotoraks. lako se uspješno odvaja od ECMO-a, pacijent je preminuo na odjelu zbog sepse $s$ multiorganskim zatajenjem. $U$ pacijentice $s$ ne-Hodgkinovim limfomom razvilo se difuzno orofaringealno i kontinuirano obostrano plućno krvarenje; sekundarna bakterijska pneumonija; opsežan pneumomedijastinum i subkutani emfizem. Unatoč svim mjerama potpore, pacijentica je preminula tokom liječenja ECMO-om zbog dekompenzacije respiracijskog zatajivanja. Zaključak: Pacijenti s hematološkim neoplazmama liječeni ECMO-om imaju loše terapijske ishode praćene čestim i teškim komplikacijama. Potrebna su klinička istraživanja $s$ posebnom pažnjom na izbor pacijenata, prevenciju, dijagnozu i liječenje komplikacija povezanih s korištenjem ECMO-a.

Ključne riječi: akutni respiracijski distresni sindrom; hematološke neoplazme; Hodgkinova bolest; izvantjelesna membranska oksigenacija; ne-Hodgkinov limfom

Although VV ECMO is increasingly being used in ICU patients as a rescue therapy for severe ARDS refractory to conventional mechanical ventilation support, the published experience on administering VV ECMO to lymphoma patients is limited to a few reports with conflicting results.

\section{INTRODUCTION}

Acute respiratory distress syndrome (ARDS) caused by pneumonia is the main reason for the intensive care unit (ICU) admissions and the predominant non-relapse cause of mortality in patients with hematologic malignancies $(\mathrm{HMs})^{1-3}$. A few recent reports show that the introduction of veno-venous extracorporeal membrane oxygenation (VV ECMO) as a rescue therapy in carefully selected patients with HMs and severe ARDS refractory to conventional mechanical ventilation support could reduce the incidence of early trea- tment-related mortality and improve long-term survival ${ }^{1,4,5}$. However, hemorrhagic diathesis and immunosuppression associated with patients with $\mathrm{HMs}$ are viewed as relative contraindications for ECMO support as they increase the risk and severity of ECMO-induced bleeding episodes and infections ${ }^{1-8}$. Some studies report less favourable outcomes, with high rates of treatmentassociated complications and low survival rates $^{2,3,6-8}$, and therefore question if such a highrisk, invasive and costly procedure is applicable to patients with HMs.

The published experience on administering VV ECMO to lymphoma patients is limited to a few reports with conflicting results ${ }^{1-3,6-8}$. Most of these studies report that lymphoma patients have better outcomes compared to patients with other subsets of HMs because of shorter periods of chemotherapy-induced bone marrow failure and subsequently fewer bleeding and infectious complications, while few report that no significant difference in complication and survival rates among different types of HMs patients exists. The purpose of our case series is therefore to report the clinical courses and outcomes of two patients, one with Hodgkin's lymphoma ( $\mathrm{HL}$ ) and one with Non-Hodgkin's lymphoma (NHL), who developed severe refractory ARDS and were treated with VV ECMO. We also compare our experience with other published reports and assess the difficulties and challenges of ECMO support in these vulnerable patients.

\section{CASE PRESENTATION}

\section{PATIENT 1}

A 41-year-old male patient was transferred from the haematology ward to the ICU because of deteriorating respiratory failure. The patient had advanced Hodgkin's lymphoma and 7 days after undergoing the sixth course of polychemotherapy he developed febrile neutropenia. Despite immediate use of repeated doses of granulocyte colony-stimulating factor (G-CSF) and empirical intravenous broad-spectrum antibiotic therapy, the fever persisted, and 10 days after chemotherapy, chest computed tomography (CT) scan depicted bilateral ground-glass opacities (GGO) with peribronchial consolidation, particularly in 
the left lung. Later in the clinical course, his respiratory status rapidly aggravated and the CT pulmonary angiogram (CTPA) revealed extensive bilateral pulmonary infiltrates and pulmonary thromboembolism in the lateral basal segment of the right lower lobe. On the $18^{\text {th }}$ day after chemotherapy he was transferred to the ICU, where his respiratory failure deteriorated further despite endotracheal intubation with protective mechanical ventilation support. VV ECMO was started on the $2^{\text {nd }}$ day of ICU treatment.

During cannulation and VV ECMO initiation the patient suffered a short cardiac arrest, with the return of spontaneous circulation after one minute following cardiopulmonary resuscitation. In order to stabilize the patient and manage the new-onset heart failure, the third cannula was introduced and VV ECMO was therefore "upgraded" to triple cannulation veno-arterial-venous ECMO (VAV ECMO) for combined hemodynamic and respiratory support. However, the transthoracic echocardiogram revealed a newly developed pericardial tamponade. Immediate pericardiocentesis was followed by sternotomy and surgical repair of the lacerated right atrial appendage. The next day the patient was hemodynamically stable and VAV ECMO was hence changed back to VV ECMO. In spite of all measures during ECMO support, like continuous broadspectrum antimicrobial therapy and G-CSF application, the patient remained intensely immunosuppressed and suffered several septic episodes with severe hemodynamic instability. Despite severe and uncorrectable thrombocytopenia and the need for anticoagulation therapy, we did not observe any bleeding episodes, however, the patient had severe thrombotic complications. Thrombosis within the membrane oxygenator led to a sudden ECMO dysfunction and the need for oxygenator replacement. The patient suffered significant right leg ischemia as a consequence of ECMO support. A decision for right leg transfemoral amputation was made after vascular surgical consultation. After 28 days of $\mathrm{VV}$ ECMO treatment, right leg amputation was performed concomitantly with ECMO discontinuation. Immediately after decannulation, the patient became cardiorespiratory unstable as the right sided tension pneumothorax developed, requiring immediate needle aspiration and chest drain insertion.

After ECMO discontinuation, percutaneous dilatational tracheostomy was performed and the patient was maintained on the protective mechanical ventilation support. As his lung function improved further, he was gradually weaned from mechanical ventilation and transferred to the hematology ward. However, the remainder of the patient's treatment course remained complicated. The patient's condition gradually deteriorated with periods of severe hemodynamic instability and a new onset of respiratory failure, which required ICU readmission. Bronchoalveolar lavage revealed Acinetobacter baumannii complex and MDR Pseudomonas aeruginosa coinfection. Despite all efforts, the patient died as a result of sepsis with multiple organ failure 60 days after the end of ECMO support.

\section{PATIENT 2}

A 47-year old female patient with advanced NonHodgkin's lymphoma was transferred from the haematology ward to the ICU because of severe respiratory insufficiency. Four days after undergoing the fourth course of polychemotherapy the patient developed febrile neutropenia. Although she was immediately treated with broad-spectrum antimicrobial therapy and several doses of G-CSF, on the $7^{\text {th }}$ day after chemotherapy she developed severe ARDS. On ICU admission a followup CT scan showed left sided pleural effusion and diffuse patchy consolidations, suggestive either of pneumonia or secondary lymphomatous involvement. Despite endotracheal intubation and protective mechanical ventilation support, her respiratory status deteriorated over the next 48 hours. VV ECMO was successfully started on the third day of her ICU treatment.

Despite all measures regarding transfusion and anticoagulation, we observed several severe bleeding episodes, most notably diffuse oropharyngeal hemorrhage on the $13^{\text {th }}$ day of ICU treatment as well as continuous bilateral pulmonary hemorrhage, which were successfully managed with massive blood component transfusions, discontinuation of systemic anticoagulation therapy and repeated bronchoscopy for extraction of endobronchial blood clots. On the $17^{\text {th }}$ day of her 
ICU treatment, a chest CT scan revealed significant progression of pulmonary findings with extensive bilateral infiltrates. Two days later MDR Pseudomonas aeruginosa was isolated in the patient's urine culture, possibly causing superimposed bacterial pneumonia. Over the next days her respiratory status gradually deteriorated despite maximal measures. On the 23rd day of ICU treatment a follow-up CT scan showed that extensive pneumomediastinum and subcutaneo-

Both our patients had significant ICU treatment costs, developed severe ECMO-induced complications, mainly bleeding incidents, thrombotic events and infections, and died prior to hospital discharge. Further studies focusing on patient selection and issues concerning prevention, diagnosis and treatment of ECMOassociated complications are needed.

us emphysema of the neck, chest and abdominal wall developed. Despite all therapeutic efforts, the patient died because of respiratory decompensation on the $26^{\text {th }}$ of her ICU treatment.

\section{DISCUSSION}

Previous reports show that ECMO therapy in patients with HMs and ARDS is associated with high rates of severe complications and low survival rates $^{2,3,6-8}$, which our experience indicates as well. Namely, both our patients had complicated treatment courses, with frequent and severe ECMOinduced complications, mainly bleeding incidents, thrombotic complications and infections.

Bleeding incidents and thrombotic complications are the most important complications of ECMO therapy in HMs patients ${ }^{2,3}$. Coagulopathy in patients with HMs undergoing ECMO support is mainly a result of two factors. Firstly, the primary illness and chemotherapy-induced bone marrow failure lead to severe and persistent thrombocytopenia ${ }^{4,5}$. Patients with HMs inherently have the highest incidence of bleeding events among all cancer patients. Keeping platelet counts above the recommended threshold during ECMO treatment is often not possible even with massive transfusions ${ }^{1}$. Moreover, this increased demand of blood transfusions raises the risk of developing transfusion related acute lung injury (TRALI), a serious complication which would lead to additional lung damage ${ }^{5}$. Secondly, haemostatic defects caused by ECMO therapy significantly raise the probability of bleeding episodes in these already susceptible patients ${ }^{4,5}$. Besides the need for systemic anticoagulation, permanent contact to the foreign surface of the extracorporeal membrane leads to increased consumption of clotting factors, reduced survival rate of platelets, activation of fibrinolysis and platelet dysfuncti$\mathrm{on}^{5}$. During ECMO treatment, and the entirety of the ICU stay, our patients required repeated blood component transfusions that were guided by results of hemograms, coagulograms and thromboelastograms. Despite all preventive measures, we observed several severe bleeding episodes in our NHL patient, most notably diffuse oropharyngeal and continuous bilateral pulmonary hemorrhage. On the other hand, our HL patient suffered severe thrombotic complications, concretely right leg ischemia, which required transfemoral amputation, and thrombosis within the membrane oxygenator. ECMO transfusion and anticoagulation strategies in both our patients were guided by current Extracorporeal Life Support Organization (ELSO) guidelines, but they suffered from severe complications nonetheless, which highlights the complexity of the prevention and treatment of both bleeding episodes and thrombosis in this patient population.

After bleeding incidents and thrombotic complications, infections are the next most significant group of ECMO-associated complications ${ }^{6}$. Patients with HMs undergoing chemotherapy have extended periods of severe leukocytopenia and are particularly at high risk of acquiring ECMO-induced septic episodes ${ }^{4,5}$. The risk of nosocomial infections rises with the duration of ICU treatment and patients with HMs and ARDS often need long-term ICU management with prolonged endotracheal intubation, mechanical ventilation and ECMO support. Ventilator-associated pneumonias have a significant role in mortality rates of patients with ECMO therapy. Strategies for infection prevention in the management of our patients, such as routine airway clearance and collection of microbiological samples, were adop- 
ted. The patients required continuous G-CSF application to stimulate recovery from severe neutropenia; and long-term broad-spectrum antimicrobial therapy, which was adjusted with frequent infectious disease consultations in relation to microbiological culture results. Despite all preventive measures, both our patients developed chemotherapy-associated febrile neutropenia followed by pneumonia and ARDS. It should be noted that chest CT scans of both patients showed infiltrations suggestive of pneumonia prior to ICU admissions and start of mechanical ventilation or ECMO support. However, all microbiological cultures were initially negative. It was only during ECMO treatment in our NHL patient, and after ECMO discontinuation in our $\mathrm{HL}$ patient, that MDR bacteria were isolated. It is unknown whether these microorganisms were part of the initial, not completely treated pneumonias or part of ICU-acquired infections. Although it is possible that these pathogens were present prior to ICU admission, we suspect that the previously present pneumonias were complicated by ventilator-associated and/or ECMO-induced bacterial super-infections.

We conclude by highlighting that both of our patients had significant ICU treatment costs, developed severe ECMO-induced complications and died prior to hospital discharge. Although VV ECMO is increasingly being used in ICU patients as a rescue therapy for severe ARDS refractory to conventional mechanical ventilation support, it seems that it is ineffective in most patients with HMs. Patients with HMs and ARDS undergoing ECMO therapy have considerably poorer outcomes than other ICU patients and there is currently no randomized controlled study that provides solid evidence to support ECMO therapy in these patients. Finally, careful and appropriate patient selection and an individualized approach regarding prevention, diagnosis and treatment of ECMO-associated bleeding incidents, thrombosis and infections should be taken.

\section{CONCLUSION}

Patients with HMs undergoing ECMO support have poor outcomes, with high rates of severe ECMO-associated complications and low survival rates. Future research should therefore focus on patient selection and issues concerning prevention, early diagnosis and treatment strategies of bleeding episodes, thrombotic complications as well as ventilator-associated and ECMO-induced infections.

Conflicts of Interest: The authors have no conflicts of interest to declare.

\section{REFERENCES}

1. Wohlfarth $P$, Ullrich R, Staudinger $T$, Bojic $A$, Robak $O$, Hermann $A$ et al. Extracorporeal membrane oxygenation in adult patients with hematologic malignancies and severe acute respiratory failure. Crit Care 2014;18:R20.

2. Park TS, Oh YN, Hong SB, Lim CM, Koh Y, Lee JH et al. Extracorporeal Membrane Oxygenation Support in Adult Patients with Hematologic Malignancies and Severe Acute Respiratory Failure. Korean J Crit Care Med 2016; 31:243-50.

3. Kang HS, Rhee CK, Lee HY, Kim YK, Kwon SS, Kim SC et al. Clinical outcomes of extracorporeal membrane oxygenation support in patients with hematologic malignancies. Korean J Intern Med 2015;30:478-88.

4. Gorjup V, Fister M, Noc M, Rajic V, Ribaric SF. Treatment of sepsis and ARDS with extracorporeal membrane oxygenation and interventional lung assist membrane ventilator in a patient with acute lymphoblastic leukemia. Respir Care 2012;57:1178-81.

5. Meister B, Zelger B, Kropshofer G, Klein-Franke A, Crazzolara $\mathrm{R}$, Frühwirth $\mathrm{M}$ et al. Extracorporeal membrane oxygenation as a rescue therapy for leukaemic children with pulmonary failure. Br J Haematol 2010;148:126-31.

6. Gow KW, Lao OB, Leong T, Fortenberry JD. Extracorporeal life support for adults with malignancy and respiratory or cardiac failure: The Extracorporeal Life Support experience. Am J Surg 2010;199:669-75.

7. Cho S, Cho WC, Lim JY, Kang PJ. Extracorporeal Life Support in Adult Patients with Hematologic Malignancies and Acute Circulatory and/or Respiratory Failure. Korean J Thorac Cardiovasc Surg 2019;52:25-31.

8. Schmidt M, Schellongowski P, Patroniti M, Taccone FS, Reis Miranda D, Reuter J et al. Sixmonth Outcome of Immunocompromised Severe ARDS patients rescued by ECMO. An International Multicenter Retrospective Study. Am J Respir Crit Care Med 2018;197:1297-307. 